\title{
Iowan Suggested Memorial Day
}

Local communities in both the North and South began to decorate the graves of fallen comrades before the end of the Civil War in 1865. The idea of setting aside a day in remembrance of the nation's war dead was acted upon by a distinguished Iowa veteran of that tragic conflict. General Norton Parker Chipman, as adjutant general of the Grand Army of the Republic in 1868, first wrote the general order designating May 30th a national memorial day, the observance of which was soon accepted by the public and is now a legal holiday in many states.

Information on the career of Norton Parker Chipman is sparse and scattered. The following sketch was prepared with the aid of the Biographical Directory of the American Congress and a History of the Grand Army of the Republic by Robert B. Beath:

General Chipman was born in Milford Center, Union County, Ohio March 7, 1834. He attended public schools, moved to Washington, Iowa in 1845, entering Washington College. He attended law school at Cincinnati and returned to Washington to be admitted to the bar and begin practice. With the outbreak of the Civil War the young lawyer enlisted in Company $\mathrm{H}$ of the famed Second Iowa Infantry May 28, 1861, and was appointed Second Lieutenant the same date. Promoted to major and adjutant of his regiment September 23rd, Chipman was severely wounded in the thigh on February 15, 1862 while leading his men in the Second Iowa's gallant charge to victory on Fort Donelson. He was appointed colonel and aid-de-camp in the regular army on April 17, and served as chief of staff to Major General Samuel R. Curtis another Iowan commanding the Army of the Southwest in Missouri. The later war years were spent in Washington where besides being detailed by President Lincoln on several dangerous and important missions. Chipman served as judge-advocate of several military courts, including the trial of Wirz, the infamous Andersonville prison keeper. He was brevetted a brigadier general of volunteers March 13, 1865 for "meritorious services in the Bureau of Military Justice," and mustered out November 30th. He settled in Washington, and upon the establishment of a territorial form of government for the District of Columbia, was appointed secretary. The former 
Iowan was also elected adjutant general of the Grand Army of the Republic in 1868, reappointed the next session by the commander-in-chief, John A. Logan, and was persuaded to continue as judge advocate in 1870 , though resigning as adjutant general because of the press of professional business. Chipman was elected a Republican Delegate to the Forty-second and Forty-third Congresses, serving from April 21, 1871 to March 3,1875, before moving to California where he engaged in the lumber business and manufacturing enterprises at Red Bluff. He became a member of the California State Board of Trade and its president from 1895 to 1906; was appointed a commissioner of the Supreme Court of California in April 1897; presiding justice of the District Court of Appeals, Third district, in 1905; elected to same in November 1906 and served until his resignation December 18, 1922. General Chipman resided in Sacramento, California, died in San Francisco February 1, 1924, and was interred in Cypress Lawn Cemetery.

The following account of the important part played by this eminent Iowa soldier in the establishment of Memorial Day is given by Robert B. Beath in his History of the Grand Army of the Republic:

Early in May 1868, Adjutant General Chipman received a letter from some comrade then living, as he remembers, in Cincinnati, in which the writer referred to the fact that he had served as a private soldier in the Union Army; that in his native country, Germany, it was the custom of the people to assemble in the springtime and scatter flowers upon the graves of the dead.

He suggested that the Grand Army of the Republic inaugurate such an observance in memory of the Union dead.

General Chipman thought the suggestion most opportune, and at once made a rough draft of a General Order covering this subject, and laid it, with the letter referred to, before General Logan.

General Logan warmly approved the Order, himself adding several paragraphs. The date selected, May 30 , was with the idea of using one of the spring months because of their poetical associations, and also to make it late in the last spring month, that it might be possible to find flowers in the New England and extreme Northern States. 
The Order [in part] reads as follows:

Headquarters Grand Army of the Republic)

Washington, D.C., May 5, 1868.)

General Orders)

No. 11

I. The 30th day of May, 1868, is designated for the purpose of strewing with flowers, or otherwise decorating the graves of comrades who died in defense of their country during the late rebellion, and whose bodies now lie in almost every city, village and hamlet churchyard in the land. . . .

II. It is the purpose of the Commander-in-Chief to inaugurate this observance with the hope that it will be kept up from year to year, while a survivor of the war remains to honor the memory of his departed comrades. He earnestly desires the public press to call attention to this Order, and lend its friendly aid in bringing it to the notice of comrades in all parts of the country in time for simultaneous compliance therewith.

III. Department Commanders will use every effort to make this Order effective.

By command of JOHN A. LOGAN, Commander-in-Chief N. P. CHIPMAN, Adjutant-General

There were many who at first doubted the wisdom of instituting such an observance. It was claimed that it would unnecessarily keep alive memories of the war, and foster animosities that should be buried in oblivion.

Other objections were made to the expense, and that the money for music and flowers could be more wisely spent on the living.

During the war there had been many instances of the decoration of soldiers' graves, and earlier than the date of this Order a "Decoration Day" had been generally observed by ex-Confederates in the Southern States. General Chipman, however, distinctly remembers the incident as already related, which directly resulted in the issue of the General Orders instituting a MEMORIAL DAY, and in his report said:

If this feature alone was the result of the organization, I think the establishment of a national memorial day a sufficient reward to our comrades for all they have done. 
Copyright of Annals of Iowa is the property of State of Iowa, by \& through the State Historical Society of Iowa and its content may not be copied or emailed to multiple sites or posted to a listserv without the copyright holder's express written permission. However, users may print, download, or email articles for individual use. 